\title{
Effects of Feeding Strategies on Growth Performance and Economic Returns on the Production of Nile Tilapia (Oreochromis niloticus) in Fertilized Ponds
}

\author{
Foster Afram ${ }^{1}{ }^{\oplus}$, Nelson Winston Agbo ${ }^{1}{ }^{\oplus}$, Daniel Adjei-Boateng ${ }^{1, *}\left(\mathbb{D}\right.$, Hillary Egna $^{2}$
}

${ }^{1}$ Department of Fisheries and Watershed Management, KNUST, Kumasi, Ghana.

${ }^{2}$ Aquafish Innovation Lab, Oregon State University, USA.

\section{How to cite}

Afram, F., Agbo, N.W., Adjei-Boateng, D., Egna, H. (2021). Effects of Feeding Strategies on Growth Performance and Economic Returns on The Production of Nile Tilapia (Oreochromis niloticus) in Fertilized Ponds. Aquaculture Studies, 21, 63-73. http://doi.org/10.4194/2618-6381-v21_2_03

\section{Article History}

Received 11 September 2020

Accepted 27 January 2021

First Online 08 February 2021

\section{Corresponding Author}

Tel.: +233243248890

E-mail: daboateng.frnr@knust.edu.gh

\section{Keywords}

Feeding strategy

Feed restriction

Growth performance

Tilapia pond culture

Profitability

\begin{abstract}
This study evaluated the effects of restrictive feeding strategies on the profitability of tilapia production in fertilized ponds. Sex-reversed tilapia fingerlings ( $60 \mathrm{~g})$ were cultured for five months under three feeding strategies; alternate-day full ration (100\%), $66.7 \%$ and $75 \%$ of full ration daily. Fish fed $75 \%$ of the full ration daily had the highest final weight $(411.3 \pm 39.32 \mathrm{~g})$, followed by fish fed $66.7 \%$ of the full ration daily $(352.0 \pm 9.17 \mathrm{~g})$ and the fish fed alternate-day full ration $(227.8 \pm 22.17 \mathrm{~g})$. Fish that received the alternate-day full ration had the lowest feed intake $\left(223.8 \pm 29.77 \mathrm{~g} \mathrm{fish}^{-1}\right)$ and a better feed conversion ratio $(1.30 \pm 0.12)$ compared to the fish fed $66.7 \%$ $(1.51 \pm 0.12)$ and $75 \%(1.52 \pm 0.09)$ of full ration daily. Crude protein, dry matter, ash content and the hepatosomatic index of the fish were not affected by the feed restriction. The crude lipid, mesenteric fat and the viscerosomatic indices were significantly $(P<0.05)$ lower in fish that received the alternate-day full ration. While the cost of production was lowest in the alternate-day ration, it had the lowest economic returns (US\$ $82.95 \pm 8.60$ ) compared to fish that received $66.7 \%$ and $75 \%$ of full ration daily (131.16 \pm 22.62 and $162.48 \pm 19.64$ US\$, respectively). These results indicated that tilapia can be cultured in fertilized ponds and fed with two-thirds of daily full ration given in intensive systems without any effect on economic returns.
\end{abstract}

\section{Introduction}

Aquaculture is the fastest growing animal production sector with a global production of 80 million tonnes in 2016 (FAO, 2018). The contribution of aquaculture to global fish production, reached $46.8 \%$ in 2016, up from $25.7 \%$ in 2000, while Africa contributed $2.5 \%$ of total aquaculture production in 2016 (FAO, 2018). Although, there is a high potential for the development of aquaculture in Africa, factors such as poor infrastructure e.g. road network, high cost of transportation of inputs, lack of support services and high cost of feed, among others limit the rapid growth of aquaculture (FAO, 2014).

One of the challenges facing the aquaculture industry is the optimal application of feed during fish culture such that fish are neither underfed nor overfed which directly or indirectly affect fish health, growth, water quality and returns on investments (Aderolu et al., 2010). Feed is an essential aspect of aquaculture, especially when fish are raised in confinement under intensive or semi-intensive systems. Feed represent the most expensive cost item in aquaculture production and contributes $40-70 \%$ of the variable cost depending on intensity (Gandotra et al., 2015; Obirikorang et al., 2015). Feed contributes significantly to commercial fish production and is the determining factor between profitable and unprofitable aquaculture business (Bolivar et al. 2006). The use of quality fish feed plays a vital role in promoting maximum growth, decrease environmental pollution and increase profit in tilapia culture (Chowdhury, 2011). Unfortunately, the use of high quality feeds by pond fish farmers is limited in Ghana, due to lack of capital and the high cost of 
complete feeds on the market (Limbu and Jumanne, 2014). Therefore, most pond farmers in Ghana rely on low quality supplemental feeds e.g. wheat bran, rice bran, groundnut husk among others leading to poor growth performance, low fish yield, and low economic returns in pond culture. Owing to this, tilapia pond culture in Ghana is seen as an unprofitable business, evidenced by the high number of farm abandonment. According to Frimpong et al. (2011) there are more than 2,800 pond farmers in southern Ghana, however, pond culture contributed less than $10 \%$ of the national aquaculture production between 2011 and 2014 due to poor quality feed among other setbacks (Rurangwa et al., 2015). However, several cost-cutting approaches have been developed to reduce feed cost, including replacing expensive animal products e.g. fishmeal with cheaper plant proteins sources (Chowdhury, 2011). Fishmeal was partially replaced by a blend of corn gluten meal, wheat meal, and soybean meal up to $20 \%$ inclusion levels (Al-Thobaiti et al., 2018); cottonseed meal up to $50 \%$ inclusion levels (Soltan et al., 2017) in Nile tilapia diets.

Other studies on feed management have shown that optimum growth and high economic returns can be achieved in tilapia culture under semi-intensive conditions by reducing the quantity of feed applied especially in fertilized ponds. Kumar et al. (2017a) reported that, since natural food is the main energy input in fish ponds, excessive supplemental feeding may result in significant economic loss, in addition to severe environmental impacts, whereas partial reduction of the feeding level may improve economic return with less environmental impact. Feeding and labour cost of Nile tilapia (Orechromis niloticus) cultured in semi-intensive fertilized ponds could be reduced by up to $50 \%$ without compromising fish growth (Brown et al., 2000; Bolivar et al., 2006; Duodo-Prah, 2014; Aliebe, 2017). The abundance of natural food in ponds as a result of fertilization is able to compensate up to $50 \%$ of supplemental feeding in Nile tilapia production with significant reduction in production costs and nutrient loading (Lin and $\mathrm{Yi}, 2003$ ). It has been observed that reduction of Nile tilapia feed to $67 \%$ of what obtains in intensively fed ponds has no negative effect on growth and yield, with considerable economic gains (Brown et al. 2000). In order to reduce the cost of feed and labor, Nile tilapia can also be subjected to alternate-day feeding where fish are fed every other day while depending entirely on natural food on days they are not fed in order to maximize natural food utilization (Bolivar et al., 2006). All these strategies have been practiced by most pond farmers unintentionally on occasions where feeds are out of stock or situations where different tasks draw farmers or workers away from their farms. This study evaluated the effects of restricted ration on the growth performance, feed utilization, body composition, water quality and economic returns of Nile tilapia cultured in fertilized ponds.

\section{Materials and Methods}

\section{Study Site and Culture System}

The experiment was carried out at the Faculty of Renewable Natural Resources (FRNR) fish farm on the campus of the Kwame Nkrumah University of Science and Technology (KNUST), Kumasi, Ghana. The experiment was conducted in nine earthen ponds with surface areas between $150-200 \mathrm{~m}^{2}$. Ponds were drained and the bottom sediments treated with sodium hypochlorite and agriculture lime at $1 \mathrm{~kg}$ and $10 \mathrm{~kg}$ per pond, respectively. The ponds were covered with a monofilament bird net to prevent predators i.e. birds and frogs from preying on the fish. Ponds were filled with groundwater to about $30 \mathrm{~cm}$ and fertilized weekly with mono ammonium phosphate (MAP) and urea at rate of $2 \mathrm{~g} \mathrm{~m}^{-2}$ and $3 \mathrm{~g} \mathrm{~m}^{-2}$ week $^{-1}$, respectively, to boost primary productivity. Pond water was topped to the $1 \mathrm{~m}$ after a week. A Secchi-disc depth was used as proxy for phytoplankton abundance.

\section{Experimental Fish and Feeding Strategies}

Sex-reversed Nile tilapia fry were obtained from a commercial hatchery at Akosombo, Eastern Region, Ghana. The fish were nursed from $1 \mathrm{~g}$ to $\sim 60 \mathrm{~g}$ before they were stocked in the experimental ponds at the rate of 2 fish $\mathrm{m}^{-2}$. Three feeding strategies; alternate-day full ration where fish received the full ration (100\%) on alternate days, $66.7 \%$ of the full ration where fish were fed $66.7 \%$ (two thirds) of the full ration daily and $75 \%$ of the full ration where fish were fed $75 \%$ (three-quarters) of the full ration daily were applied. The three feeding strategies (treatments) were randomly assigned to the ponds in triplicates. The full ration (100\%) given daily which would have been the control was not included in the trial, because the current study is a follow-up to earlier studies (Duodo-Prah, 2014; Aliebe, 2017) to finetune the optimum feeding level for tilapia culture in fertilized ponds.

Prior to the start of the experiment fish were acclimatized to the experimental ponds for a week during which they were fed at $3 \%$ body weight (full ration) with a commercial tilapia feed. Fish were fed daily between 9:30 - 10:30 am and 3:00 - 4:00 pm for five months. The amount of feed given was adjusted daily based on the expected daily growth rate of the fish, however, fish were sampled monthly to recalibrate the daily full ration. The commercial tilapia feed (Raanan Fish Feed West Africa, Ghana) used for the trial contained $30 \%$ crude protein and $5 \%$ lipid.

\section{Growth Performance and Feed Utilization}

Fifty fish from each pond were randomly sampled every thirty days to determine the weight gain and to adjust the feed. Growth performance and feed 
utilization were determined using the following parameters;

$W G(g)=$ Final fish weight $(g)$ - Initial fish weight $(g)$

WG: Weight Gain

$$
P W G=\frac{F F W(g)-I F W(g)}{\text { Initial fish weight }(g)} \times 100
$$

PWG: Percentage Weight Gain

FFW: Final Fish Weight

IFW: Initial Fish Weight

$$
A G R(g / \text { day })=\frac{F F W-I F W}{\text { Culture period }(\text { days })}
$$

AGR: Absolute Growth Rate

FFW: Final Fish Weigh

IFW: Initial Fish Weight

$$
\operatorname{SGR}(\% / \text { day })=\frac{\operatorname{In}(F F W)-\operatorname{In}(I F W)}{\text { Culture period }(\text { days })} \times 100
$$

SGR: Specific Growth Rate

FFW: Final Fish Weight

IFW: Initial Fish Weight

$$
F C R=\frac{\text { Average feed intake }(g)}{\text { Average weight gain of fish }(g)}
$$

FCR: Feed Conversion Ratio

$$
S R=\frac{\begin{array}{c}
\text { Number of fish } \\
\text { at the end of the experiment }
\end{array}}{\text { Number of fish }} \times 100
$$

SR: Survival Rate

$$
F E R=\frac{\text { Average weight gain of fish }(g)}{\text { Average feed intake }(g)}
$$

FER: Feed Efficiency Ratio

$$
\text { Feed intake }(g / f i s h)=\frac{\text { Total feed given }(g)}{\text { Total number of fish }}
$$

\section{Water Quality Monitoring}

Water quality data were taken every two weeks between 7 and $8 \mathrm{am}$ in the morning throughout the experimental period. The following physicochemical variables were determined; dissolved oxygen (DO), conductivity, temperature, and $\mathrm{pH}$ were taken in-situ using $\mathrm{HACH}$ (HQ 40d) multi-parameter probe at three points, the shallow, middle and deeper portions of the pond. The sensor of the probe was immersed to about
$30 \mathrm{~cm}$ below the pond water surface during water quality monitoring. Secchi-disc readings were measured at three points, the shallow, middle and deeper portions of the pond. The mean value of the three measurements for each pond was used as Secchi depth for the pond. Water samples from each pond were collected $30 \mathrm{~cm}$ below the surface, into $500 \mathrm{ml}$ plastic bottles wrapped with black polythene. The water samples were kept on ice and transported to the water quality laboratory of the Faculty of Renewable Natural Resources (FRNR) and analyzed for nitrite-nitrogen, nitrate-nitrogen, total alkalinity, phosphate and chlorophyll $a$. The Wagtech photometer was used to determine the concentration of nitrite-nitrogen, nitrate-nitrogen, total alkalinity, and phosphate by the use of corresponding reagents (Wagtech protocol). Chlorophyll $a$ was used as a proxy for primary productivity. Concentration of chlorophyll $a$ was measured according to the standard procedure described in HMSO (1983).

\section{Biometric Parameters}

At the end of the experiment, nine fish were randomly selected from each treatment for hepatosomatic index, mesenteric fat index and viscerosomatic index analysis to assess the physiological status of the fish and fat accumulation. To avoid overestimation of these variables, the fish were starved for $24 \mathrm{~h}$ prior to the performance the analyses to ensure complete evacuation of the gut. The fish were anaesthetized and weighed individually with an electronic weighing balance. The fish were then dissected to remove the liver, mesenteric fat and total visceral contents separately and weighed. Thirty fish were randomly selected from each treatment at the end of the experiment to determine the condition factor. The weight and length of the fish were measured with an electronic balance and measuring board, respectively. Values for hepatosomatic index, mesenteric fat index, viscerosomatic index and condition factor were calculated as:

$$
V I=\frac{\text { Weight of Visceral organs }}{\text { Weight of fish }} \times 100
$$

VI: Viscerosomatic Index

$$
\begin{gathered}
\text { Hepatosomatic Index }=\frac{\text { Weight of Liver }}{\text { Weight of fish }} \times 100 \\
M F I=\frac{\text { Weight of Mesenteric fat }}{\text { Weight of fish }} \times 100
\end{gathered}
$$

MFI: Mesenteric Fat Index

$$
\text { Condition factor }=\frac{\text { Weight of fish }}{(\text { Total length })^{\wedge} 3} \times 100
$$




\section{Determination of Body Composition}

Six fish from each treatment were randomly selected at the end of the experiment. The whole fish was blended, and kept frozen until analysis. The fish samples from each treatment were analyzed for their proximate composition using standard methods (AOAC, 2005). Crude protein was determined by the Kjeldahl method, crude lipid was determined by Bligh and Dyer (1959) method, dry matter was determined after oven drying of the samples at $105^{\circ} \mathrm{C}$ for $24 \mathrm{~h}$ and ash contents were determined from weight loss after incineration of the samples at $550^{\circ} \mathrm{C}$ for $4 \mathrm{~h}$ in a muffle furnace.

\section{Cost-Benefit Analysis}

A simple enterprise budget was used to evaluate the economic performance of fish under the three feeding strategies. On-farm fixed and variable cost data were used to assess the profitability of the feeding strategies. Variable costs included the cost of feed, fingerlings, fertilizers, sodium hypochlorite, agricultural lime and labour (pond preparation, feeder and harvesters). Revenue for the experiment was solely based on the sale of fish at farm gate prices. Cost of labour was estimated at 2.15 US\$ per day whereas the unit price of feed used was 0.78 US\$ per kg. Prices of materials and sale of fish were based on the prevailing local market prices as well as the exchange rate of the Ghana Cedis (GHC) to the United States Dollar (1US\$=4.92GHC) in December 2018.

\section{Statistical Analysis}

Data were analyzed using Graphpad Prism 5.1 statistical software. All data were subjected to one-way analysis of variance (ANOVA) and differences among the treatment means were compared by the Tukey's multiple comparison test. Differences were considered significant at $\alpha=0.05$ level. Simple correlation analysis was employed to derive relationship between feed intake and SGR, crude lipid, and mesenteric fat index. The results from the experiment were presented as Mean \pm Standard Error (SE).

\section{Results}

\section{Growth Performance, Feed Utilization and Yield}

The growth performance and feed utilization of tilapia cultured under the three feeding strategies are presented in Table 1. Generally, there was a steady increase in fish weight over the experimental period, however, the growth rate declined in the fifth month in all the treatments. However, fish that received $66.7 \%$ and $75 \%$ of full ration daily had a significantly higher final mean weight $(352.0 \pm 9.17 \mathrm{~g}$ and $411.3 \pm 22.70 \mathrm{~g}$, respectively) compared to the fish in alternate-day full ration treatment $(227.8 \pm 22.17 \mathrm{~g})$. Weight gain ( $\mathrm{g} \mathrm{fish}^{-1}$ ) was significantly higher in fish that received the $75 \%$ ration than the other treatments. Similarly, the $75 \%$ ration treatment had a higher absolute growth rate (AGR) $\left(2.33 \pm 0.11 \mathrm{~g} \mathrm{fish}^{-1} \mathrm{day}^{-1}\right)$ compared to the other treatment. Although, the specific growth rate (SGR) was slightly better for $75 \%$ ration, it did not differ $(P=0.073)$ from the other treatments.

The cumulative feed intake (g fish ${ }^{-1}$ ) was significantly lower $(P=0.0016)$ in fish that received alternate-day ration than the fish receiving $66.7 \%$ and $75 \%$ ration treatments. Consequently, fish that were maintained on the alternate-day full ration had the best feed conversion ratio, whereas fish that received the $66.7 \%$ and $75 \%$ of the full ration daily had a similar feed efficiency. The FCR and feed efficiency ratio (FER) did not differ $(\mathrm{P}=0.332)$, among the treatments. Similarly, there was no difference $(P=0.894)$ in fish survival rate among

Table 1. Growth performance, feed utilization and yield (Mean $\pm \mathrm{SE}, \mathrm{n}=3$ ) of Nile tilapia (Oreochromis niloticus) under restrictive feeding strategies over a five-month period.

\begin{tabular}{|c|c|c|c|c|}
\hline & \multicolumn{3}{|c|}{ Feeding Strategies } & \multirow[b]{2}{*}{ P Value } \\
\hline & $\begin{array}{l}\text { Alternate Day } \\
\text { Full Ration }\end{array}$ & $66.7 \%$ of Full Ration & $75 \%$ of Full Ration & \\
\hline Initial mean weight (g) & $55.57 \pm 11.28$ & $59.44 \pm 8.26$ & $62.36 \pm 11.51$ & 0.9009 \\
\hline Final mean weight (g) & $227.8 \pm 22.17^{a}$ & $352.0 \pm 9.17^{b}$ & $411.3 \pm 22.70^{b}$ & 0.0014 \\
\hline Percentage Weight Gain & $327.5 \pm 50.23$ & $509.2 \pm 61.41$ & $591.6 \pm 92.62$ & 0.0905 \\
\hline Weight Gain (g fish-1) & $172.2 \pm 13.84^{a}$ & $292.6 \pm 3.74^{b}$ & $349.0 \pm 17.11^{c}$ & 0.0002 \\
\hline Absolute Growth Rate (g fish ${ }^{-1}$ day $^{-1}$ ) & $1.15 \pm 0.09^{a}$ & $1.95 \pm 0.02^{\mathrm{b}}$ & $2.33 \pm 0.11^{c}$ & 0.002 \\
\hline Specific Growth Rate $\left(\%\right.$ day $\left.^{-1}\right)$ & $0.96 \pm 0.08$ & $1.20 \pm 0.07$ & $1.28 \pm 0.09$ & 0.0727 \\
\hline Survival (\%) & $90.97 \pm 2.23$ & $92.17 \pm 1.64$ & $91.69 \pm 1.40$ & 0.8942 \\
\hline Feed Conversion Ratio & $1.30 \pm 0.12$ & $1.51 \pm 0.12$ & $1.52 \pm 0.09$ & 0.3326 \\
\hline Feed Efficiency Ratio & $0.78 \pm 0.07$ & $0.67 \pm 0.05$ & $0.67 \pm 0.04$ & 0.2992 \\
\hline Feed Intake (g fish-1) & $223.8 \pm 29.77^{a}$ & $442.8 \pm 36.01^{b}$ & $530.5 \pm 33.42^{b}$ & 0.0016 \\
\hline Total Feed Given (kg pond ${ }^{-1}$ ) & $80.13 \pm 3.08^{a}$ & $159.8 \pm 3.00^{\mathrm{b}}$ & $192.3 \pm 6.81^{c}$ & $<0.0001$ \\
\hline Feed Given (kg hectare ${ }^{-1}$ ) & $4477 \pm 595.3^{a}$ & $8856 \pm 720.3^{b}$ & $10610 \pm 668.3^{b}$ & 0.0016 \\
\hline Total Fish Yield (kg pond $\left.{ }^{-1}\right)$ & $74.76 \pm 4.53^{a}$ & $118.70 \pm 10.03^{b}$ & $137.30 \pm 9.74^{b}$ & 0.0052 \\
\hline Fish Yield $\left(\mathrm{kg}\right.$ hectare $\left.{ }^{-1}\right)$ & $4122 \pm 302.5^{a}$ & $6483 \pm 80.7^{b}$ & $7531 \pm 310.9^{b}$ & 0.0002 \\
\hline
\end{tabular}

Means in the same row with different superscripts differ significantly at $\mathrm{P}<0.05$. Absence of letters indicate no significant differences among the treatments. 
the treatments. Fish in all three feeding strategies had above $90 \%$ survival rates. However, fish that received $66.7 \%$ and $75 \%$ ration had a significantly higher fish yield $(118.70 \pm 10.03 \mathrm{~kg}$ and $137.30 \pm 9.74 \mathrm{~kg}$ per pond, respectively) compared to the alternate-day treatment (74.76 $\pm 4.53 \mathrm{~kg}$ per pond).

A weak positive correlation $(r=0.268 ; P=0.154)$ was observed between feed intake $\left(\mathrm{g} \mathrm{fish}^{-1}\right)$ and specific growth rate $\left(\%\right.$ day $\left.^{-1}\right)$. Although, the feed restriction did not have a significant effect on feed utilization and survival, it significantly affected the final weight (g), weight gain $(\mathrm{g})$, yield $\left(\mathrm{kg} \mathrm{pond} \mathrm{p}^{-1}\right.$ ) and feed intake ( $\mathrm{g}$ fish $^{-1}$ ) of tilapia.

\section{Biometric Parameters and Body Composition}

The biometric parameters and body composition of Nile tilapia cultured under three feeding strategies are presented in Table 2 . The results showed highly significant differences in mesenteric fat index, viscerosomatic index $(P=0.0001)$ and dressout percentage $(P=0.0001)$ among the treatments. Fish fed the 75 and $66.7 \%$ ration had a higher viscerosomatic index (9.35 -8.25\%) and mesenteric fat index (3.46 $2.15 \%)$, compared to fish that received the alternateday ration $(7.37 \pm 0.15 \%$ and $0.74 \pm 0.17 \%$, respectively). Both mesenteric fat index and viscerosomatic index had a linear decrease with increasing feed restriction. However, fish that received alternate-day ration had the highest dress-out percentage $(92.63 \pm 0.15 \%)$ which decreased with decreasing feed restriction. Although, the hepatosomatic index of the fish followed a similar trend as the viscerosomatic index and mesenteric fat index, no significant differences $(P=0.356)$ were observed among the treatments. No differences $(P=0.084)$ were observed for the condition factor $(K)$ of tilapia cultured under the different feeding strategies, although, fish fed the $75 \%$ of had the highest value. With respect to the whole body composition of tilapia under the three feeding strategies, no differences were found in crude protein $(P=0.329)$, dry matter $(P=0.661)$ and ash content $(P=0.095)$ of the fish among the treatments. Although, dry matter and crude lipid had a linear decrease with increasing feed restriction, the ash content increased with increasing feed restriction. Fish that received $75 \%$ of the full ration had a higher crude lipid level which decreased with increasing feed restriction. A moderate positive correlation ( $r=0.557$; $\mathrm{P}=0.021$ ) was observed between feed intake $\left(\mathrm{g} \mathrm{fish}^{-1}\right)$ and crude lipid content (\%) in the whole body composition. However, a strong positive correlation ( $r=0.9047 ; P<0.0001)$ was observed between the feed intake ( $\mathrm{g} \mathrm{fish}^{-1}$ ) and the mesenteric fat index (\%).

\section{Water Quality}

The physicochemical variables monitored i.e. dissolved oxygen, temperature, $\mathrm{pH}$ and alkalinity in the culture ponds were not affected by the feeding strategies (Table 3). However, the alternate-day full ration treatment had a significantly lower $(P=0.0004)$ conductivity. All the water quality variables were within the optimum range for tilapia culture (Boyd, 1990). The best dissolved oxygen level $\left(3.0 \pm 0.43 \mathrm{mg} \mathrm{l}^{-1}\right)$ was recorded in the alternate-day ration treatment. There was a general decrease in dissolved oxygen levels in all treatments from the start of the experiment to the end. There was no difference in Secchi disc reading ( $P=0.738)$ among the feeding strategies. Feed restriction had no effect on nitrite, nitrate and phosphate $(P>0.05)$ levels in the pond water. Chlorophyll a (proxy for primary productivity) was also not affected by the feeding strategies. Chlorophyll a concentration and phosphate levels in the pond water showed a steady increase in all the treatments from the start of the experiment until termination.

Table 2. Biometric parameters and body composition (Mean $\pm \mathrm{SE}, \mathrm{n}=3$ ) of Nile tilapia (Oreochromis niloticus) under restrictive feeding strategies over a five-month period.

\begin{tabular}{|c|c|c|c|c|}
\hline & \multicolumn{3}{|c|}{ Feeding Strategies } & \multirow[b]{2}{*}{ P Value } \\
\hline & $\begin{array}{l}\text { Alternate Day } \\
\text { Full Ration }\end{array}$ & $\begin{array}{l}66.7 \% \text { of the } \\
\text { Full Ration }\end{array}$ & $\begin{array}{l}75 \% \text { of the } \\
\text { Full Ration }\end{array}$ & \\
\hline \multicolumn{5}{|l|}{ Biometric parameters } \\
\hline Viscerosomatic index (\%), & $7.37 \pm 0.15^{\mathrm{a}}$ & $8.25 \pm 0.16^{b}$ & $9.35 \pm 0.35^{c}$ & 0.0001 \\
\hline Hepatosomatic index (\%), & $2.05 \pm 0.29$ & $2.26 \pm 0.09$ & $2.52 \pm 0.24$ & 0.3563 \\
\hline Mesenteric fat (\%), & $0.74 \pm 0.17^{a}$ & $2.15 \pm 0.38^{b}$ & $3.46 \pm 0.43^{c}$ & 0.0002 \\
\hline Dress-out percentage (\%) & $92.63 \pm 0.15^{\mathrm{a}}$ & $91.75 \pm 0.16^{b}$ & $90.65 \pm 0.35^{c}$ & 0.0001 \\
\hline Condition Factor (K) & $1.93 \pm 0.03$ & $1.98 \pm 0.04$ & $2.06 \pm 0.04$ & 0.0840 \\
\hline \multicolumn{5}{|l|}{ Body composition } \\
\hline Dry matter (\%) & $29.05 \pm 0.42$ & $29.82 \pm 0.11$ & $30.15 \pm 1.26$ & 0.6043 \\
\hline Crude protein (\%) & $16.68 \pm 0.39$ & $16.78 \pm 0.20$ & $16.05 \pm 0.39$ & 0.3296 \\
\hline Crude lipid (\%) & $8.35 \pm 0.19^{a}$ & $9.89 \pm 0.64^{\mathrm{ab}}$ & $10.95 \pm 0.73^{b}$ & 0.0186 \\
\hline Ash (\%) & $5.28 \pm 0.22$ & $3.92 \pm 0.22$ & $3.88 \pm 0.66$ & 0.0952 \\
\hline Moisture (\%) & $70.87 \pm 0.42$ & $70.18 \pm 0.06$ & $69.85 \pm 1.26$ & 0.6409 \\
\hline
\end{tabular}

Means in the same row with different superscripts differ significantly at $\mathrm{P}<0.05$. Absence of letters indicate no significant differences among the treatments. 
Table 3. Water quality variables (Mean $\pm \mathrm{SE}, \mathrm{n}=3$ ) of Nile tilapia (Oreochromis niloticus) production under restrictive feeding strategies over a five-month period.

\begin{tabular}{lcccc}
\hline & \multicolumn{3}{c}{ Feeding Strategies } \\
\cline { 2 - 5 } & Alternate Day & $66.7 \%$ of the & $75 \%$ of the & Full Ration \\
\hline Temperature $\left({ }^{\circ} \mathrm{C}\right)$ & Full Ration & $28.0 \pm 0.28$ & $28.0 \pm 0.29$ & 0.9429 \\
Dissolved Oxygen $\left(\mathrm{mgl}^{-1}\right)$ & $28.0 \pm 0.28$ & $2.27 \pm 0.43$ & $2.85 \pm 0.47$ & 0.4674 \\
pH & $3.01 \pm 0.43$ & $7.38 \pm 0.05$ & $7.53 \pm 0.05$ & 0.0931 \\
Conductivity $\left(\mu \mathrm{Scm}^{-1}\right)$ & $7.43 \pm 0.05$ & $105.70 \pm 5.10^{\mathrm{b}}$ & $123.10 \pm 6.10^{\mathrm{a}}$ & 0.0004 \\
Alkalinity $\left(\mathrm{mgl}^{-1}\right)$ & $91.58 \pm 3.80^{\mathrm{a}}$ & $129.90 \pm 15.0$ & $134.20 \pm 5.30$ & 0.2573 \\
Secchi depth $(\mathrm{cm})$ & $106.80 \pm 9.70$ & $15.80 \pm 1.20$ & $14.56 \pm 0.92$ & 0.7381 \\
Turbidity $(\mathrm{NTU})$ & $15.00 \pm 1.20$ & $49.87 \pm 7.60$ & $44.70 \pm 6.80$ & 0.3929 \\
Nitrite $\left(\mathrm{mgl}^{-1}\right)$ & $64.37 \pm 15.0$ & $0.01 \pm 0.004$ & $0.31 \pm 0.30$ & 0.3683 \\
Nitrate $\left(\mathrm{mgl}^{-1}\right)$ & $0.01 \pm 0.004$ & $0.76 \pm 0.19$ & $0.90 \pm 0.21$ & 0.8517 \\
Phosphate $\left(\mathrm{mgl}^{-1}\right)$ & $0.89 \pm 0.18$ & $49.90 \pm 5.10$ & $57.58 \pm 5.30$ & 0.2573 \\
Chlorophyll a $\left(\mu \mathrm{gl}^{-1}\right)$ & $63.75 \pm 7.00$ & $341.20 \pm 78.12$ & $448.10 \pm 96.76$ & 0.5132 \\
\hline Means
\end{tabular}

Means in the same row with different superscripts differ significantly at $\mathrm{P}<0.05$. Absence of letters indicate no significant differences among the treatments.

\section{Cost-Benefit Analysis}

The cost of feed and labour varied significantly among the three feeding strategies (Figure 1). However, all other production costs were the same regardless of the feeding strategy. Fish that received the alternateday full ration had a significantly lower feed cost, contributing $43.3 \%$ of the total production cost, whereas the feed cost in fish maintained on the $66.7 \%$ and $75 \%$ of the full ration daily were $54.3 \%$ and $58.8 \%$, respectively. The contribution of labour to the production cost was lowest in fish that received the alternate day ration (12.5\%), while labour constituted $15.64 \%$ and $14.10 \%$ of production cost in the $66.7 \%$ and $75 \%$ ration groups, respectively. Although, there were variations in the total cost of production and fish yield, the breakeven price above the cost of production did not vary significantly $(P=0.717)$. The breakeven price obtained for the treatments was 2.03 US\$, with the $66.7 \%$ feeding level recording the highest breakeven price (Table 4). The fish were sold for 3.09 US\$ per kilogram on KNUST campus. The variation in fish yield resulted in significant differences $(P=0.005)$ in revenue from fish sales (Figure 2). All three feeding strategies had a positive net returns on investment (Table 4). Fish that received the alternate-day ration had a lower net return compared to fish that were fed at $66.7 \%$ or $75 \%$ of the full ration daily. However, the highest economic efficiency was obtained in fish fed at $75 \%$ of the full ration.

\section{Discussion}

\section{Growth Performance and Feed Utilization}

The results of the present study showed that feed restriction or partial feeding affected growth performance of tilapia with respect to the final weight attained, weight gain and absolute growth rate. Although, the specific growth rate and percentage weight gain were not affected, there was a direct relationship between growth performance and increasing feed restriction (Table 1). The poor performance of fish fed on alternate days can be attributed to lower feed intake. According to Riche et al. (2004), a positive relationship exists between feed intake and fish growth. The results showed a positive relationship between feed intake and growth performance, although weak. Thus, feeding Nile tilapia beyond a certain threshold does not influence fish growth but rather increases production cost (Dawood et al., 2019).

The growth performance observed in this study is in contrast with the observations of Diana et al. (2004); Bolivar et al. (2006) and Aliebe (2017). According to these authors, growth was not negatively affected in Nile tilapia fed on alternate days or maintained on a reduced ration up to half the normal rate $(2-3 \%$ body weight) in fertilized ponds. The authors reported that natural food was enhanced by pond fertilization to contribute substantially to tilapia growth, thus, pond fertilization could provide up to $50 \%$ of the required nutrition. However, the results of this study showed that, feeding Nile tilapia on alternate-days resulted in a substantial drop in growth attributable to insufficient feed compared to the other feeding levels.

The growth performance was slightly better in fish that received $75 \%$ of the ration compared to the $66.7 \%$ treatment, although, no differences were found between the two treatments. The decrease in growth during the last month of the experiment in all treatments could be attributed to lower temperatures (harmattan) during the period as feed intake was lower in all the treatments owing to a drop in water temperature by $3^{\circ} \mathrm{C}$ from $28^{\circ} \mathrm{C}$ in the previous months. The feed conversion ratio (FCR) was not affected by the feed restriction. The FCR was better in fish that were maintained on the alternate-day ration than the $66.7 \%$ and $75 \%$ of the ration (Table 1). This affirms the fact that, the fish benefited from natural food which was 


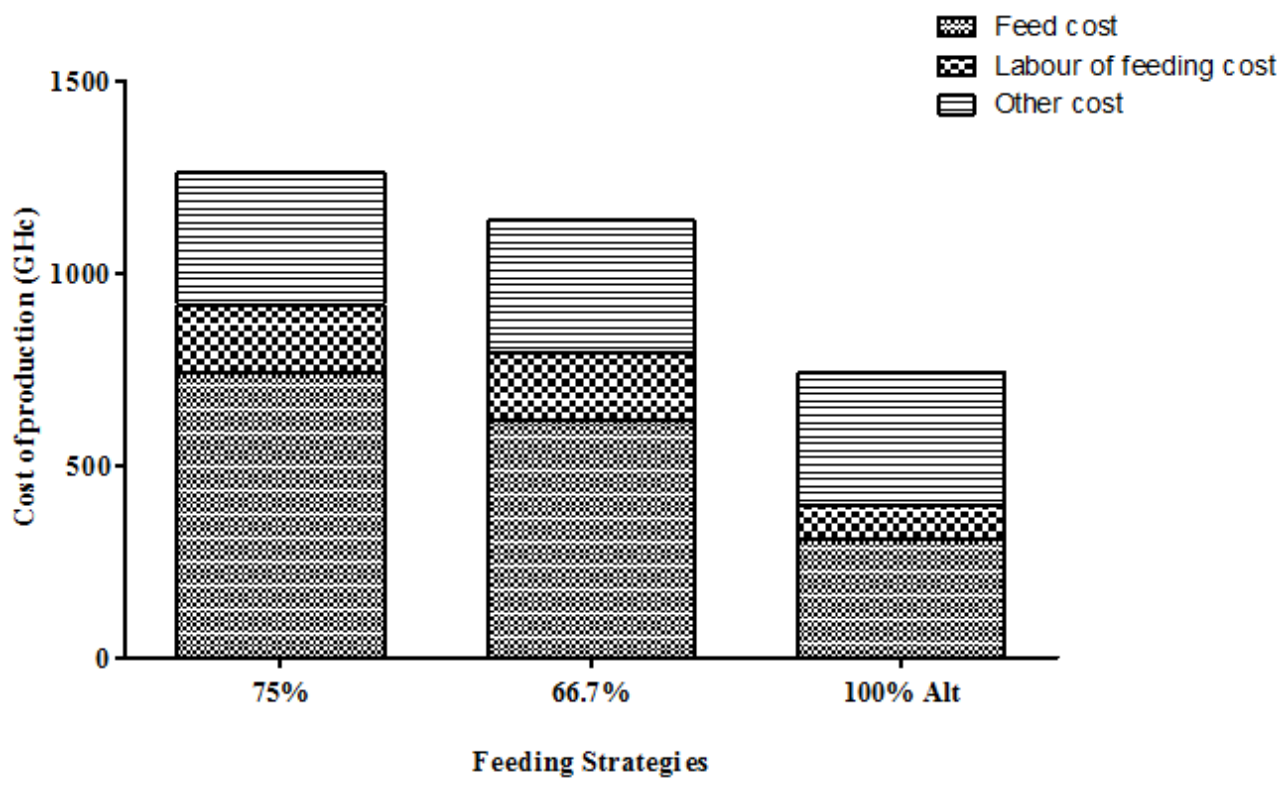

Figure 1. Cost of Nile tilapia production under restricted feeding strategies $(66.7 \%, 75 \%$ ration and full ration on alternative day) over a six-month period on KNUST campus, Kumasi, Ghana

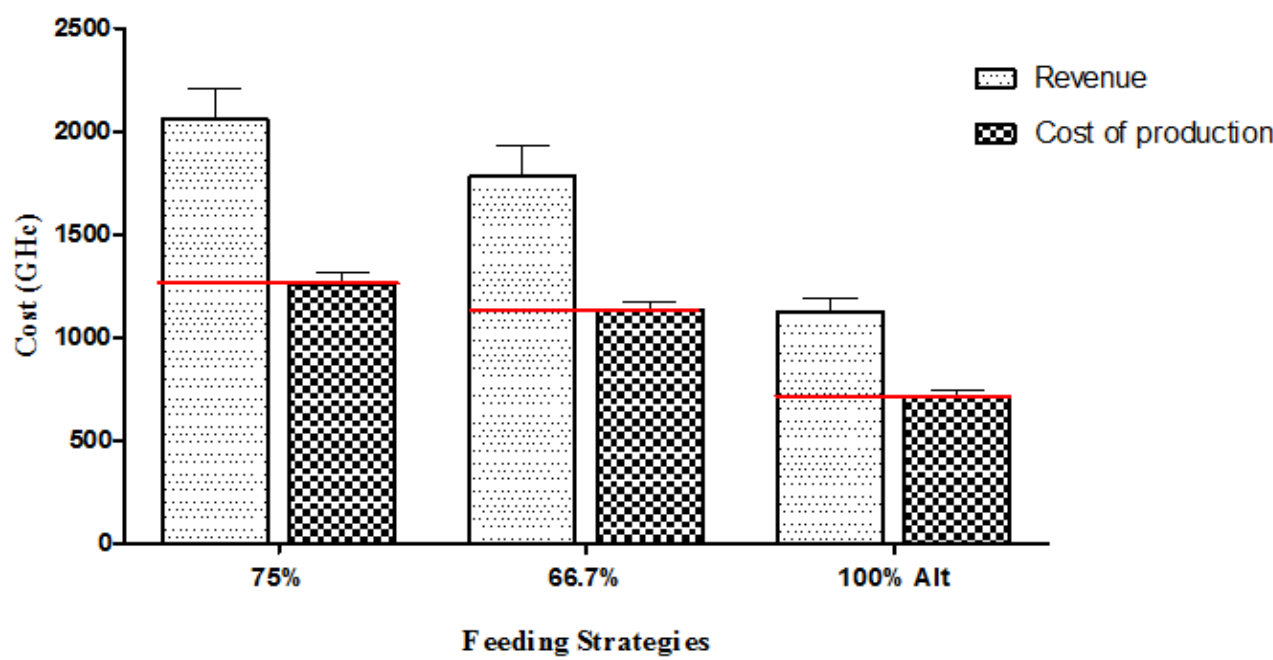

Figure 2. Cost of production and revenue of Nile tilapia under restricted feeding strategies $(66.7 \%, 75 \%$ ration and full ration on alternative day) over a six-month period on KNUST campus, Kumasi, Ghana

Table 4. Economic analysis of Nile tilapia production (Mean $\pm S E, n=3$ ) under restrictive feeding strategies over a five-month period.

\begin{tabular}{|c|c|c|c|c|}
\hline & \multicolumn{3}{|c|}{ Feeding Strategies } & \multirow[b]{2}{*}{$P$ value } \\
\hline & $\begin{array}{l}\text { Alternate Day } \\
\text { Full Ration }\end{array}$ & $\begin{array}{c}66.7 \% \text { of the } \\
\text { Full Ration }\end{array}$ & $\begin{array}{l}75 \% \text { of the } \\
\text { Full Ration }\end{array}$ & \\
\hline Total feed given $\left(\mathrm{kg}\right.$ pond ${ }^{-1}$ ) & $80.13 \pm 3.08^{a}$ & $159.80 \pm 3.00^{b}$ & $192.30 \pm 6.81^{c}$ & $<0.0001$ \\
\hline Total fish yield (kg pond $\left.{ }^{-1}\right)$ & $74.76 \pm 4.53^{a}$ & $118.70 \pm 10.03^{b}$ & $137.30 \pm 9.74^{b}$ & 0.0052 \\
\hline Feed cost $\left(\mathrm{GH} \ell\right.$ pond $\left.^{-1}\right)$ & $308.50 \pm 11.86^{a}$ & $615.00 \pm 11.55^{b}$ & $740.40 \pm 26.22^{c}$ & $<0.0001$ \\
\hline Labour cost $\left(\mathrm{GH} \ell\right.$ pond $\left.^{-1}\right)$ & $88.50 \pm 0.00$ & $177.00 \pm 0.00$ & $177.00 \pm 0.00$ & \\
\hline Other variable cost $\left(\mathrm{GH} \varnothing\right.$ pond $\left.^{-1}\right)$ & $311.70 \pm 28.33$ & $311.70 \pm 28.33$ & $311.70 \pm 28.33$ & 1.0000 \\
\hline Total variable cost $\left(\mathrm{GH} \ell\right.$ pond $\left.^{-1}\right)$ & $708.70 \pm 20.95^{a}$ & $1,103.70 \pm 39.80^{\mathrm{b}}$ & $1,229.10 \pm 54.18^{b}$ & 0.0002 \\
\hline Fixed cost $\left(\mathrm{GH} \ell\right.$ pond $\left.^{-1}\right)$ & $31.25 \pm 0.00$ & $31.25 \pm 0.00$ & $31.25 \pm 0.00$ & \\
\hline Total production cost $\left(\mathrm{GH} \ell\right.$ pond $\left.^{-1}\right)$ & $739.95 \pm 31.52^{\mathrm{a}}$ & $1134.95 \pm 39.80^{b}$ & $1260.35 \pm 54.18^{b}$ & 0.0002 \\
\hline Total revenue $\left(\mathrm{GH} \varnothing\right.$ pond $\left.^{-1}\right)$ & $1,121.00 \pm 67.92^{\mathrm{a}}$ & $1,780.00 \pm 150.40^{b}$ & $2,060.00 \pm 146.10^{\mathrm{b}}$ & 0.0052 \\
\hline Breakeven price ( $\mathrm{GH} \varnothing \mathrm{kg}^{-1}$ fish) & $9.57 \pm 0.29$ & $9.65 \pm 0.53$ & $9.22 \pm 0.30$ & 0.7166 \\
\hline Profit $\left(\mathrm{GH} \ell\right.$ pond $\left.^{-1}\right)$ & $408.10 \pm 42.31^{\mathrm{a}}$ & $645.30 \pm 111.3^{\mathrm{ab}}$ & $799.40 \pm 96.64^{b}$ & 0.0536 \\
\hline Economic efficiency (\%) & $57.09 \pm 4.58$ & $56.31 \pm 8.16$ & $63.08 \pm 5.43$ & 0.7171 \\
\hline
\end{tabular}

Means in the same row with different superscripts differ significantly at $P<0.05$. Absence of letters indicate no significant differences among the treatments. Exchange rate 1US\$ $=4.92 \mathrm{GH} \not$ in December 2018 . 
enhanced through fertilization and was efficiently utilized by the fish as alluded by Diana (1994). Wang et al. (2006) reported that, the basal metabolic rate in fish usually reduces during periods of food restriction leading to a large portion of ingested feed being utilized for tissue growth instead of basal metabolism, which could have accounted for the better feed conversion efficiency in the alternate-day ration (Limbu and Jumanne, 2014). Other studies on hybrid tilapia (AbdelHakim et al., 2009), Nile tilapia (Passinato et al., 2015), European seabass (Dicentrarchus labrax) (Adakli and Tasbozan, 2015) and Mozambique tilapia (Oreochromis mossambicus) (Gabriel et al., 2017) reported an improved feed utilization in fish subjected to restricted feeding. Survival in all the treatments was over $90 \%$ and was not affected by feed restriction. The high survival rate could be attributed to the bird net used to screen the ponds and the larger fingerling used $(\sim 60 \mathrm{~g})$ for the trial. This shows that mortality due to predation in tilapia ponds can be reduced significantly by stocking larger fingerlings (Bolivar et al., 2004) and screening the ponds before stocking.

\section{Biometric Parameter and Body Composition}

The feeding strategies had no effect on feed utilization, thus, did not influence the body composition of the fish except crude lipid. There was no difference in dry matter, crude protein, moisture and ash content in the body composition of tilapia (Table 2). Increasing feed restriction in Nile tilapia was accompanied by a decrease in dry matter and crude lipid, whereas moisture and ash contents increased with increasing feed restriction (Ali et al., 2016). Crude protein did not follow any pattern, with the $75 \%$ treatment recording the lowest value. This could be attributed to the higher body lipid in fish that received the $75 \%$ ration. The results on crude protein content is in contrast to the findings of Wang et al. (2000); Ali et al. (2016) and Gabriel et al. (2017), who reported a decrease in the crude protein content with increasing feed restriction in juvenile hybrid tilapia, Nile tilapia and Mozambique tilapia, respectively. Thus, protein deposition in fish decreases with increasing feed restriction. However, the findings of Gao et al. (2015), and Adakli and Tasbozan (2015) on feed restriction in Nile tilapia and European seabass respectively, are in accordance with the results on crude protein content of fish in this study. The moisture content of tilapia increased with increasing feed restriction (Ali et al., 2016). According to Martinez et al. (1994) and Rueda et al. (1998), an inverse relationship exists between crude lipid and moisture content in fish as shown in this study, there was a replacement of muscle lipid with moisture in the tissues. Similarly, Wang et al. (2000) reported that, tilapia body moisture and ash are likely to increase, while crude lipid and dry matter decrease as feed restriction increases.

The viscerosomatic and mesenteric fat indices as well as the dress-out percentage observed in this study were significantly influenced by feed restriction (Table 2). The significantly higher mesenteric fat in fish that received $75 \%$ of the full ration daily accounted for the higher viscerosomatic index and lowest dress-out percentage. Viscerosomatic and mesenteric fat indices are important attributes that directly affect fish yield (Wang et al., 2005). Thus, a higher fat deposit can reduce dress-out weight and commercial value of the fish product (Otwell and Rickards, 1981). Although, tilapia fat contains some amount of omega-3 fatty acids, which is associated with reducing cardiovascular diseases, it contains more omega- 6 fatty acids regarded as less healthy than omega-3 (Pearson, 2017). Accordingly, tilapia fat does not offer the recommended 1:1 omega- 6 to omega- 3 fatty acids ratio unlike other fish fat. It is also believed that, omega- 6 fatty acids can be harmful and increase inflammation in humans if consumed in excess (Simopoulos, 2016). Moreover, tilapia fat is mostly deposited around the visceral organs, which is not consumed except few producers who extract the fat for other uses, hence does not pose a threat to consumers. However, the mesenteric fat is not beneficial to most producers, but could rather affect fish health especially when deposition occurs in the liver. Perez and Oliva-Teles (1999) reported that, excessive deposition of fat in fish could strongly influence nutritional value, organoleptic properties and storage time of fish. The feed restriction did not affect the hepatosomatic index in this study. This indicates that fish liver in all the treatments were normal with no abnormal storage of fat. Ali et al. (2016) reported that, depriving Nile tilapia of feed for one to three days in a week did not affect the hepatosomatic index, however, the hepatosomatic index decreased with increasing feed restriction. The lower whole body lipid and mesenteric lipid levels in fish that received the alternate-day full ration could be attributed to the short-term starvation, during which the lipid was used as an energy source (Weatherley and Gill, 1987).

\section{Water Quality}

The physicochemical variables monitored during the experiment were all within the optimum range for tilapia culture in ponds (Boyd, 1990). The variables were not affected by the treatments, except conductivity. The gradual decrease in dissolved oxygen towards the end of the trial could be attributed to an increase in phytoplankton abundance, as a result of nutrient loading (faecal matter) from the increasing fish biomass. The higher organic matter level in addition to the increasing fish biomass depressed dissolved oxygen levels, especially early morning concentration. However, the lower morning temperatures recorded during the dry season resulted in a slightly better dissolved oxygen levels due to high dissolution of oxygen and low metabolic activities (Sajitha and Vajiyamma, 2016). The low nitrite levels recorded in the study can be attributed to the rapid conversion of nitrite to nitrate by nitrogen 
fixing bacteria making the nitrate available for phytoplankton growth. Warm temperatures combined with abundant phytoplankton led to utilization of nitrate by phytoplankton in the ponds (Pahlow and Oschlies, 2009). This contributed to the low levels of nitrate measured in all the treatments. However, the high levels of phosphate in the alternate-day treatment accompanied by a low chlorophyll a concentration indicates a lower phosphate uptake by the phytoplankton (Pahlow and Oschlies, 2009). Both turbidity and chlorophyll a were not affected by feed restriction, as depicted by the positive relationship between turbidity and chlorophyll $a$. This indicates that phytoplankton contributed much to the turbidity of the pond water (Gallagher et al., 2016).

\section{Cost Benefit Analysis}

The economic performance shows that all the feeding strategies are profitable, however the best profit was recorded in the $75 \%$ ration treatment. Feed cost decreased with increasing feed restriction, indicating that feed restriction resulted in a lower production cost (Limbu and Jumanne, 2014). This, offers an opportunity for tilapia pond farmers to reduce the cost of production while increasing profitability by feeding at least $66.7 \%$ of the full ration daily. While the cost of production was lowest in fish that received the alternate-day ration, it had the lowest economic returns compared to fish that received $66.7 \%$ and $75 \%$ of the full ration daily. This is in contrast to the findings of Diana et al. (1996), Brown et al. (2000), Bolivar et al. (2006) and Aliebe (2017), who reported higher economic returns in fish that received the alternate-day ration. Feed represented (40-60\%) of production cost of Nile tilapia in semi-intensive system as reported by Gandotra (2015), Kumar et al. (2017b) and Daniel (2018). Labor cost in feeding was the second largest (12-15\%) of total production cost in this study. Similar findings were reported by Riche et al. (2004) and Aliebe (2017) on the contribution of labor to the total cost of production. Severe feed restriction (alternate-day ration) had a negative effect on fish growth and economic returns, with the worst results on growth and economic performance (Abdel-Hakim et al., 2009). El-Araby et al. (2020) also reported that, feeding Nile tilapia every other day or every third day can compromise fish growth and economic returns.

\section{Conclusion}

The ration of Nile tilapia can be reduced up to $66.7 \%$ of the daily full ration given in intensive systems without significantly compromising the growth performance and feed utilization. Feed restriction in Nile tilapia production did not affect the body composition and biometric parameters, but had the tendency of reducing fat deposition. Feed restriction had no effect on pond water quality and significantly reduced production cost, but negatively affected the profitability of fish fed on alternative days since fish yield was significantly lower compared to the other treatments. Thus, Nile tilapia can be cultured in fertilized ponds and fed at least two-thirds of the daily full ration given in intensive systems, without any effect on growth and economic returns.

\section{Ethical Statement}

The study was conducted in accordance with the Animal Research and Ethics Committee (AREC), KNUST, Ghana, the body responsible for regulating the use of animals for research https://www.knust.edu.gh/sites/default/files/201902/ AREC\%20Reviewed\%202018.pdf).

\section{Funding Information}

Funding for this work was provided by the former Feed the Future AquaFish Innovation Lab, a programme funded in part by the United States Agency for International Development (USAID) through Oregon State University, USA, and the Kwame Nkrumah University of Science and Technology.

\section{Author Contribution}

FA: Methodology, Formal Analysis, Investigation, Visualization, Writing-Original Draft. NWA: Conceptualization, Supervision, Writing-Review \& Editing, Funding Acquisition. DA-B: Conceptualization, Writing-Review \& Editing, supervision. HE: Conceptualization, mobilization of resources, funding acquisition.

\section{Conflict of Interest}

The authors declare no conflict of interest in the publication of this scientific paper.

\section{Acknowledgement}

The authors are grateful to AquaFish Innovation Lab and the United Stated Agency for International Development (USAID) for providing financial support to undertake this study.

\section{References}

Abdel-Hakim N.F., Abo State H.A., Al-Azab A.A., and El-Kholy K.F. (2009). Effect of feeding regimes on growth performance of juvenile hybrid Tilapia (Oreochromis niloticus $\mathrm{x}$ Oreochromis aureus). World Journal of Agriculture Science, 5(1):49-54.

Adakli, A., \& Tasbozan, O. (2015). The effects of different cycles of starvation and refeeding on growth and body composition on European seabass (Dicentrarchus labrax). Turkish Journal of Fisheries and Aquatic Science, $15,419-427$. 
Aderolu, A.Z., Seriki, B.M., Apatira, A.L., and Ajaegbo. C.U. (2010). Effects of feeding frequency on growth, feed efficiency and economic viability of rearing African catfish (C. gariepinus, Burchell 1822) fingerlings and juveniles. African Journal of Food Science, 4 (5), 286-290.

Ali, T. E. S., Martínez-Llorens, S., Moñino, A. V., Cerda, M. J., \& Tomás-Vidal, A. (2016). Effects of weekly feeding frequency and previous ration restriction on the compensatory growth and body composition of Nile tilapia fingerlings. The Egyptian Journal of Aquatic Research, 42(3), 357-363.

Aliebe, A. (2017). Effect of Different Feeding Strategies On Growth Performance and Economic Returns of Nile Tilapia (O. niloticus) Production in Semi-intensive System. (MSc thesis submitted to the Kwame Nkrumah University Of Science And Technology, Kumasi, Ghana, $71 \mathrm{pp}$

Al-Thobaiti, A., Al-Ghanim, K., Ahmed, Z., Suliman, E. M., \& Mahboob, S. (2018). Impact of replacing fish meal by a mixture of different plant protein sources on the growth performance in Nile Tilapia (Oreochromis niloticus L.) diets. Brazilian Journal of Biology, 78(3), 525-534.

AOAC (2005). Official methods of analysis of the Official Association of Analytical Chemists, 18th edn. Association of the Official Analytical Chemists, Arlington

Bligh, E., G., and Dyer, W.J. (1959). A rapid method of total lipid extraction and purification. Canadian Journal of Biochemistry and Physiology, 37(8), 911-917.

Bolivar R. B., Jimenez E. B. T., and Christopher, L. B. (2006). Alternate-Day Feeding Strategy for Nile Tilapia Grow Out in the Philippines: Marginal Cost-Revenue Analyses. North American Journal of Aquaculture 68:192-197, 2006.

Boyd, C. E. (1990). Water Quality in Ponds for Aquaculture. Alabama Agriculture Experiment Station, Auburn University, Alabama, USA.

Brown, C.L., R. B. Bolivar, E. T. Jimenez and J. Szyper. (2000). Timing of the onset of supplemental feeding of Nile tilapia (Oreochromis niloticus) in ponds. In: Fitzsimmons, K. and Filho, J.C. (eds) Tilapia Culture in the 21st Century. Proceeding of the $5^{\text {th }}$ International Symposium on Tilapia Aquaculture., American Tilapia Association and ICLARM, Rio de Janeiro, Brazil, pp. 237-240.

Chowdhury D. K. (2011). Optimal feeding rate for Nile tilapia (Oreochromis niloticus). Masters theses. Norwegian University of Life Sciences. Dept. of Animal and Aquacultural Sciences (IHA), $76 \mathrm{pp}$.

Daniel, N. (2018). A review on replacing fish meal in aqua feeds using plant protein sources. International Journal of Fisheries and Aquatic Studies, 6(2), 164-179.

Dawood, M. A., Eweedah, N. M., Moustafa Moustafa, E., \& Shahin, M. G. (2019). Effects of feeding regimen of dietary Aspergillus oryzae on the growth performance, intestinal morphometry and blood profile of Nile tilapia (Oreochromis niloticus). Aquaculture Nutrition, 25(5), 1063-1072.

Diana, J. S., Lin C. K. and Jaiyen K. (1994). Supplemental feeding of tilapia in fertilized ponds. Journal of the World Aquaculture Society 25:497-506.

Duodo-Prah, C. (2014). Effects of pond fertilization and feeding levels on of productivity Nile tilapia (Oreochromis niloticus) in Ghana. Msc. Thesis submitted to the Kwame Nkrumah University of Science and Technology, Kumasi, Ghana, $88 \mathrm{pp}$.
El-Araby, D. A., Amer, S. A., \& Khalil, A. A. (2020). Effect of different feeding regimes on the growth performance, antioxidant activity and health of Nile tilapia, Oreochromis niloticus. Aquaculture, 735572.

FAO. (2018). The State of World Fisheries and Aquaculture 2018 - Meeting the sustainable development goals. Rome.

Food and Agriculture Organization (FAO) (2014). The State of World Fisheries and Aquaculture 2012. Food and Agricultural Organization of the United Nations. Rome, Italy. Available at: www.fao.org/3/a-i3720e.pdf.

Frimpong, E.A., Quagrainie, K.K., Amisah, S., Agbo, N.W., \& Anane-Taabeah, G. (2011). Harnessing the Opportunities and Overcoming the Constraints to Widespread Adoption of Cage Aquaculture in Ghana. Final Project Report Submitted to United States Agency for International Development Aquaculture and Fisheries Collaborative Research Support Program. Corvallis, Oregon.

Gabriel, N.N., Omoregie, E., Tjipute, M., Kukuri, L., \& Shilombwelwa, L. (2017). Short-term cycles of feed deprivation and refeeding on growth performance, feed utilization, and fillet composition of hybrid tilapia (Oreochromis mossambicus $\times 0$. niloticus). The Israeli Journal of Aquaculture-Bamidgeh, IJA_69.2017.1344.

Gallagher, J. B., Hoe, C. C., Yusob, M. S. B. M., Gen, C. N., \& Mae, G. Y. (2016). Surface chlorophyll patchiness across Sepanggar Bay: Relationships with turbidity and depth. Transactions on Science and Technology, 3(2), 421-426.

Gandotra, R., Kumari, R. and Parihar, D. S. (2015). Impact of varied dietary protein on the growth performance of the juveniles of Labeo rohita. Journal of Environmental Biology, 2(3), pp. 652-655.

Gao, Y., Wang, Z., Hur, J. W., \& Lee, J. Y. (2015). Body composition and compensatory growth in Nile tilapia Oreochromis niloticus under different feeding intervals. Chinese journal of oceanology and limnology, 33(4), 945956.

Kumar, A., Ravi, C., Chanu, T.I., Mishra, S., Kumar, U., and Das, P.C. (2017a). Effect of different Weaning strategies on survival and growth of Endangered Fish Pengba Osteobrama belangeri (Valenciennes, 1844) larvae. International Journal of Pure Applied Bioscience 5(5), 951-957

Kumar, P., Jain, K. K., MunilKumar, S., \& Sudhagar, S. A. (2017b). Alternate feeding strategies for optimum nutrient utilization and reducing feed cost for semiintensive practices in aquaculture system-A review. Agricultural Reviews, 38(2), 145-151.

Limbu, S. M., and Jumanne, K. (2014). Effect of restricted and re-feeding regime on feeding cost, growth performance, feed utilization and survival rate of mixed sex Nile tilapia Oreochromis niloticus cultured in tanks. International Journal of Fisheries and Aquatic Studies 2(1), 118-123.

Lin, C. K., \& Yi, Y. (2003). Minimizing environmental impacts of freshwater aquaculture and reuse of pond effluents and mud. Aquaculture, 226(1), 57-68.

Martinez F.J., Garcia-Riera M.P., and Zamora S. (1994). Diet energy distribution and use in rainbow trout. Aquaculture Magazine 20, 56-64.

Obirikorang, K. A., Amisah, S., Fialor, S. C., \& Skov, P. V. (2015). Digestibility and postprandial ammonia excretion in Nile tilapia (Oreochromis niloticus) fed diets containing different. Aquaculture international, 23(5), 1249-1260. 
Otwell, W.S., Rickards, L.W., 1981. Cultured and wild American eels, A. rosfrata: fatcontent and fatty acid composition. Aquaculture 26, 67-76.

Pahlow, M., \& Oschlies, A. (2009). Chain model of phytoplankton $\mathrm{P}, \mathrm{N}$ and light colimitation. Marine Ecology Progress Series, 376, 69-83.

Passinato, B.E., de Magalhaes Junior, F.O., Cipriano, S.F, de Souza, B.H.R, de Lima, S.K., Chiapetti, J., \& Braga, T.G.L. (2015). Performance and economic analysis of the production of Nile tilapia submitted to different feeding regime. Supplemento, 36(6), 4481- 4492. http://dx.doi.org/10.5433/1679$359.2015 v 36 n 6 S u p l 2 p 4481$.

Pearson, K. (2017). Tilapia Fish: Benefits and Dangers. Healthline. October, 11, 2017.

Riche, M., Oetker, M., Haley, D.I., Smith, T. And Garling, D.L. (2004). Effect of Feeding Frequency on Consumption, Growth, and Efficiency in Juvenile tilapia (Oreochromis niloticus). The israeli Journal of Aquaculture-Bamidgeh, 56: 247-255.

Rueda, F.M., Martinez, S., Zamora, M., and Kentouri, P. (1998). Divanach, Effect of fasting and refeeding on growth and body composition of red porgy (Pagrus pagrus L.). Aquaculture Research, 29, 447- 452. http://dx.doi.org/10.1046/j.1365-2109.1998.00228.x.
Rurangwa, E., Agyakwah, S.K., Boon, H., \& Bolman, B.C. (2015). Development of Aquaculture in Ghana: Analysis of the fish value chain and potential business cases (No. C021/15). IMARES

Sajitha V., and Smitha Asok Vijayamma, (2016). Study of Physico-Chemical Parameters and Pond Water Quality Assessment by using Water Quality Index at Athiyannoor Panchayath, Kerala, India. Emer Life Sciences Research, 2(1): 46-51.

Simopoulos, A. P. (2016). An increase in the omega-6/omega3 fatty acid ratio increases the risk for obesity. Nutrients, 8(3), 128.

Soltan, M.A., El-sayed, A.I. Iraqi, M.M., Goda, A.M. Hassaan, M.S. \& Ramadan, H. A. (2017). Optimum inclusion level of cotton seed meal as a source of protein in the diets of Nile tilapia, Oreochromis niloticus diet. Annals of Agricultural Science, 55(4), 825-830.

Wang T., Hung C.C.Y., and Randall D.J. (2006). The comparative physiology of food deprivation: From feast to famine. Annual Review of Physiology, 68:223-251.

Wang, Y., Cui, Y., Yang, Y., \& Cai, F. (2000). Compensatory growth in hybrid tilapia (Oreochromis mossambicus $\times 0$. niloticus) reared in seawater. Aquaculture 189, 101-108.

Weatherley, A.H and Gill, H.S. (1987). The biology of Fish Growth. Academic press, London, UK. 443pp. 